\title{
African Studies Fellowship Program of the Ford Foundation
}

Grants providing for post-graduate work on the histories, cultures, and current problems of African peoples have recently been awarded under the second year of the Foreign Study and Research Fellowship Program of the Ford Foundation. The aim of the Program is to enable an increased number of Americans to acquire training and experience in understanding and handling problems of foreign areas, so as to meet needs arising from the United States' increased international responsibilities.

The recipients of African fellowships awarded in 1955 include:

Dr. Ethel M. Albert, of Harvard University, who, after six months' study in England and France, will spend one year in Ruanda-Urundi investigating the beliefs, laws, and values of the people, with special attention to misunderstanding arising in their relations with Europeans.

Mr. Warren L. d'Azevedo (Northwestern University) will spend 18 months in Western Liberia studying the Gola peoples, with special reference to social and historical factors connected with their long and continuing resistance to outside cultural influence.

Mr. William J. Barber, after continuing economic research at Nuffield College, Oxford, for six months, will spend six months in the Central African Federation studying the economy of the Federation, with special reference to the effect of fluctuating American demands for raw materials.

Mr. Fred G. Burke (Princeton) will study local government in Uganda, with special reference to the assimilation of democratic processes and values.

Mr. Ronald Cohen will investigate the effect of modern commerce on the economy and social system of the Kanuri of Bornu, Nigeria.

Mr. Eugene P. Dvorin, of the University of California, Los Angeles, plans to study the emergence of federalism in Central Africa in the course of a year's work in Southern Rhodesia, placing emphasis on the development of the civil services and on the division of powers among the Governments concerned.

Dr. John S. Galbraith (University of California, Los Angeles), working for one year in the United Kingdom and South Africa, will study the British-South African conflict over the status of Bechuanaland, Basutoland, and Swaziland.

Mr. Robert G. Gregory (University of California, Los Angeles) will make an historical study of the background to the Mau Mau problem in Kenya, tracing the causes and effects of government policy over the past half-century.

Dr. Marvin Harris (Columbia University) will study the effects of Portuguese colonial policy upon African life in Mozambique, P.E.A., working for about a year among the Bathonga.

Mr. Robert A. LeVine (Harvard) will conduct an 18 -months' study of personality development in a tribal society in West Uganda.

Mr. David K. Marvin will continue his studies at Northwestern University on the political systems of African tribes, with special attention to political changes under the influence of Western administrations.

Mr. Elliott P. Skinner (Columbia) will study for 6 months in Paris and a year in French West Africa the effects of European contact on the Mossi of Haute-Volta. He will pay special attention to the seasonal migrations of labour.

Mr. Arthur Tuden (Northwestern University) will spend 18 months studying hereditary chieftainship among the Ila peoples of Northern Rhodesia.

Dr. Roger William Wescott (African studies program, Boston University) plans to undertake a linguistic study in Edo-speaking communities in Western Nigeria.

Mr. Immanuel M. Wallerstein (Columbia University) will spend one year at Nuffield 
College, Oxford, to prepare for a study of the growth of voluntary organizations providing a structural basis for democratic society in French and/or British West Africa.

\section{Institute of African-American Relations}

THIs Institute, with headquarters in Washington, D.C., has as its aims the strengthening of African-American relations, and in particular the assisting of African students in the United States. To this end it has since January 1955 operated a Scholarship Program whereby financial assistance is provided for African students resident at an educational institution in the United States. It has also organized an essay competition, offering prizes for essays by African students on the subject of African-American Relations. Six prizes were awarded, while seven essays received honourable mention. The winner of the first prize, a Nigerian, is studying for the degree of M.A. in Education at the University of Chicago. The Institute plans to open an African House in Washington, to serve as a place of meeting, study, and recreation for African students as well as a centre for programmes for local Americans. The Institute publishes a periodical Bulletin.

\section{L'Éducation de Base}

M. Le Gouverneur Deschamps a présenté une communication au sujet de l'éducation de base devant le Comité Central de la France d'Outre-mer, le 25 mars 1959 . L'éducation de base, dit M. Deschamps, est une méthode d'éducation totale des collectivités arriérées. Il s'agit d'apprendre à ces collectivités, non seulement les rudiments de l'écriture, de la lecture et du calcul, mais les méthodes permettant d'améliorer leur sort en général, c'est à dire, l'hygiène, la construction, l'agriculture, l'élevage, tout ce qui touche à leur mode de vie traditionnel. Ce système avait pris naissance dans le Mexique et s'était passé à UNESCO, qui avait essayé d'étendre ce plan à d'autres pays sous-développés. Des centres internationaux avaient été créés par l'UNESCO en Amérique et dans le Moyen-Orient; l'efficacité de cette action internationale était encore discutable, mais elle avait éveillé l'idée de l'éducation de base, et la Commission Culturelle de l'UNESCO avait créé un sous-comité présidé par M. Senghor et le Professeur Rivet. Ce sous-comité avait permis d'apprendre un certain nombre de choses sur la manière dont les expériences se déroulaient de par le monde, ainsi que l'intérêt qu'elles présentent. Dans les territoires français de l'Afrique un premier essai avait été fait à M'Boumba en I95 I; un autre avait eu lieu à Darau Mousti (voir Africa, xxv, 3, 1955, p. 289), région où les gens étaient nettement hostiles à l'instruction. Néanmoins, l'équipe d'Éducation de Base avait réussi à créer des contacts: des champs avaient été mis en culture, le bétail avait été vacciné, les malades avaient été soignés. D'autres expériences étaient en cours au Sénégal, en Côte d'Ivoire, au Dahomey, au Togo. Un centre de moniteurs d'Éducation de Base a été créé en A.O.F., en vue de les préparer à ces techniques tout à fait particulières. Au Cameroun avait été créé un Comité Territorial et un Bureau de l'Éducation de Base, dépendant de la Direction de l'Enseignement, sous la direction de M. Pauvert, sociologue, qui avait procédé à des enquêtes sociales préliminaires très étendues. Une formule originale était le Journal de Nyong et Sanaga, lancé par M. Pauvert-un journal de villages édité par les gens du pays (voir Africa, xxiv, 1, 1954, p. 63). En A.E.F. il y avait eu la tentative de M. Fourré (voir Africa, xxv, 1, 1955, p. 95) mais, sauf au Sénégal et au Cameroun, il n'existait pas d'organisation.

La création du Conseil Supérieur de l'Éducation de Base, et l'affectation d'une somme de 800 millions destinée à une période de quatre ans marquaient une étape dans l'histoire de l'Éducation de Base dans les territoires français.

Le Conseil Supérieur de l'Éducation de Base a tenté de dégager une doctrine qui comprend 